\title{
Ten Years-long Survey on Pathogen Status of Mouse and Rat Breeding Colonies
}

\author{
Masaro NAKAGAWA, Manabu SAITO, Eiko SUZUKI, Kazue NAKAYAMA, \\ Junko MATSUBARA and Takeshi MUTO
}

Department of Veterinary Science, National Institute of Health 10-35 Kamiosaki 2-chome, Shinagawa-ku, Tokyo 141, Japan

(Received 28 March 1983 / Accepted 27 September 1983)

\begin{abstract}
Eleven pathogens including $P$. aeruginosa, Salmonella spp., E. coli O115a, $c$ : K (B), P. pneumotropica, B. bronchiseptica, C. kutscheri, Tyzzer's organism, $M$. pulmonis, Sendai virus, MHV and Syphacia spp. were surveyed in 217 mouse and rat breeding colonies during 1972-1981. In conventional animals, $P$. pneumotropica and / or Syphacia spp. were detected in nearly $90 \%$ of 89 mouse and 64 rat colonies. Sendai virus, $M$. pulmonis, $P$. aeruginosa and MHV were positive in 51.7 to 23.6 $\%$ of the colonies, and Tyzzer's organism, B. bronchiseptica and probably SDA virus were also detected in more than $10 \%$ of the rat colonies. Salmonella spp., E. coli O115a, c: K (B) and C. kutscheri were found in a few colonies. In SPF animals, $P$. aeruginosa was isolated from about one third of 33 mouse and 31 rat colonies, and $P$. pneumotropica was also positive in 3 rat colonies, Infection rates of $P$. pneumotropica, M. pulmonis, Sendai virus and Syphacia spp. were usually higher than $40 \%$ of animals sampled from colonies contaminated with them. Accidental contaminations of SPF colonies were usually caused by $P$. pneumotropica and Syphacia spp.
\end{abstract}

Pathogen status of laboratory mice and rats in this country has been extensively examined these 10 years by several investigators $[3,4,14,16]$, indicating the prevalence of infections with Sendai virus, mouse hepatitis virus, Mylcoplasma pulmonis, Bordetella bronchiseptica, Tyzzer's organism and pinworms. However, many of them used the serological and parasitological techniques for the survey, and therefore some important bacterial infections undetectable by the techniques were excluded from their results.

In our laboratory, serological, bacteriological and parasitological examinations have been made on important pathogens of mice and rats which were sent for microbiological monitoring of breeding colonies by many institutions and commercial breeders all over the country since 1972. In this paper, results of 10 years-survey over 1972-1981 are presented with some epizootiological analyses concerning on transmissions of the pathogens.

Animal samples older than 8 weeks of age were delivered directly from breeding colonies to our laboratory. Within 5 hours after arrival, they were sacrificed by taking blood from the heart under anesthesia with chloroform and submitted to examinations on the following pathogens; Pseudomonas aeruginosa, Salmonella spp., Escherichia coli O115a, 
Table 1. Pathogen status of mouse and rat breeding colonies

\begin{tabular}{|c|c|c|c|c|}
\hline \multirow{2}{*}{ Pathogen } & \multicolumn{2}{|c|}{ Mouse } & \multicolumn{2}{|c|}{ Rat } \\
\hline & SPF & Conv. & SPF & Conv. \\
\hline$P$. aeruginosa & $11(33.3)$ & $28(31.5)$ & $11(35.5)$ & $25(39.1)$ \\
\hline Salmonella spp. & 0 & $4(4.5)$ & 0 & 0 \\
\hline E. coli $\mathrm{O} 115 \mathrm{a}, \mathrm{c}: \mathrm{K}(\mathrm{B})$ & 0 & $5(5.6)$ & NT & NT \\
\hline P. pneumotropica & 0 & $66(74.2)$ & $3(9.7)$ & $45(70.3)$ \\
\hline B. bronchiseptica & NT & NT & 0 & $9(14.1)$ \\
\hline C. kutscheri & 0 & $2(2.2)$ & 0 & $5(7.8)$ \\
\hline Tyzzer's organism & 0 & $5(5.6)$ & 0 & $11(17.2)$ \\
\hline M. pulmonis & 0 & $21(23.6)$ & 0 & $24(37.5)$ \\
\hline Sendai virus & 0 & $46(51.7)$ & 0 & $19(29.7)$ \\
\hline MHV (Probably SDA in rat) & 0 & $23(25.8)$ & 0 & $7(10.9)$ \\
\hline Syphacia spp. & 0 & $66(74.2)$ & 0 & $34(53.1)$ \\
\hline No. of colonies examined & 33 & 89 & 31 & 64 \\
\hline
\end{tabular}

( ) : Per cent NT: Not tested

$\mathrm{c}: \mathrm{k}(\mathrm{B})$, Pasteurella pneumotropica, Bordetella bronchiseptica, Corynebacterium kutscheri, Tyzzer's organism, Mycoplasma pulmonis, Sendai virus, mouse hepatitis virus (MHV) and Syphacia spp.

Swab samples of the external nares and trachea including pharyngo-larynx area were cultured on blood agar, DHL agar (Eiken Co., Tokyo) and PPLO agar for detection of $P$. pneumotropica [11], B. bronchiseptica [9] and M. pulmonis[12], respectively. Cecal content was submitted to cultivation of $E$. coli O115a,c: $\mathrm{k}(\mathrm{B})[10]$, $P$. aeruginosa [7] and $C$. kutscheri by use of DHL agar, NAC agar (Eiken Co., Tokyo) and nutrient agar in which agar content was increased to 3.0 per cent to prevent swarming of Proteus spp. [8], respectively. Salmonella spp. was also examined by cultivating cecal content on MacConkey agar (Eiken Co., Tokyo) after enrichment in Selenite broth (Eiken Co., Tokyo) [15]. Syphacia obvelata and S. muris were checked by the perianal cellophane tape method [1] and examination of cecal content. Identifications of the bacteria and pinworms were made according to descriptions in the literatures cited above for detection of each pathogen, except for $C$. kutscheri which was identified according to criteria by Utsumi et al [17] and Weisbroth and Scher [19]

Complement fixation (CF) test was performed in individual serum by Kolmer's microtitration method [14] for detection of antibodies to Sendai virus, MHV and Tyzzer's organism. Antigen of Sendai virus was made from chick embryos inoculated with $\mathrm{H}$ strain of the virus according to the method described previously[13]. Antigens of MHV and Tyzzer's organism, both of which were made from the mouse liver inoculated with $\operatorname{Pr}$ strain of MHV-2 and TyR strain of rat Tyzzer, respectively, [3], were kindly supplied by Prof. K. Fujiwara, University of Tokyo.

Pathogen status was examined in a total of 217 different mouse and rat breeding colonies $(3,735$ animals $)$, from which at least 10 and more animal samples older than 8 weeks of age were obtained, during 1972 to 1981. Results are shown in Table 1.

It was apparent from the Table 1 that $P$. pneumotropica and Syphacia spp. were main contaminants in conventional mouse and rat colonies; 66 each $(74.2 \%)$ of 89 mouse colonies examined were 
Table 2. Rates of animals positive for main pathogens in breeding colonies

\begin{tabular}{|c|c|c|c|c|c|c|c|}
\hline \multirow{2}{*}{ Animal } & \multirow[t]{2}{*}{ Pathogen } & \multirow{2}{*}{$\begin{array}{l}\text { No. of } \\
\text { positive } \\
\text { colonies }\end{array}$} & \multicolumn{5}{|c|}{$\begin{array}{l}\text { No. of colonies showing the } \\
\text { following percent positive }\end{array}$} \\
\hline & & & $1-20$ & $21-40$ & $41-60$ & $61-80$ & $81-100(\%)$ \\
\hline \multirow{6}{*}{ Mouse } & P. aeruginosa & 39 & 16 & 9 & 6 & 2 & 6 \\
\hline & P. pneumotropica & 66 & 1 & 9 & 14 & 17 & 25 \\
\hline & M. pulmonis & 21 & 1 & 1 & 3 & 5 & 11 \\
\hline & Sendai virus & 46 & 2 & 2 & 5 & 6 & 31 \\
\hline & MHV & 26 & 16 & 6 & 1 & 1 & 2 \\
\hline & Syphacia & 66 & 13 & 19 & 14 & 10 & 10 \\
\hline \multirow{8}{*}{ Rat } & P. aeruginosa & 36 & 15 & 4 & 9 & 3 & 5 \\
\hline & P. pneumotropica & 48 & 1 & 9 & 10 & 4 & 24 \\
\hline & B. bronchiseptica & 9 & 2 & 2 & 2 & 1 & 2 \\
\hline & Tyzzer's organism & 11 & 7 & 3 & 1 & 0 & 0 \\
\hline & M. pulmonis & 24 & 1 & 1 & 0 & 1 & 21 \\
\hline & Sendai virus & 19 & 2 & 1 & 2 & 2 & 12 \\
\hline & MHV (Probably SDA) & 7 & 4 & 0 & 1 & 1 & 1 \\
\hline & Syphacia & 34 & 1 & 8 & 6 & 7 & 12 \\
\hline
\end{tabular}

contaminated with these pathogens, and $45(70.3 \%)$ and $34(53.1 \%)$ of 64 rat colonies were found to be contaminated with $P$. pneumotropica and Syphacia spp., respectively. Thus a total of 80 mouse colonies $(89.9 \%)$ and 55 rat colonies $(85.9$ $\%$ ) were contaminated with $P$. pneumotropica and/or Syphacia spp. Contaminations of other pathogens such as Sendai virus, M. pulmonis, $P$. aeruginosa and $\mathrm{MHV}$ were fairly common in conventional animals, being positive in 51.7 to 23.6 per cent of all colonies examined. In rats, Tyzzer's organism and B. bronchiseptica were also positive in more than 10 per cent of 64 conventional colonies. Although MHV antibody was positive in $7(10.9 \%)$ of 64 rat conventional colonies, this antibody probably indicated sialodacryoadenitis (SDA) virus infection, because the two viruses have a common antigen [2] and prevalence of SDA virus infection in rats has been found in this country $[4,6$, 18]. Almost all Salmonella spp. and $C$. kutscheri positive colonies were found early in the survey period. None of the conventional mouse and rat colonies was free from all the pathogens examined.
In SPF colonies, $P$. aeruginosa was a predominant pathogen in both mice and rats, and there was no difference in detection rates of the organism between SPF and conventional colonies. Although no other pathogen was found in SPF mouse colonies, $P$. pneumotropica was an additional contaminant in only 3 SPF rat colonies.

Percentages of animals positive for main pathogens within contaminated colonies are summarized in Table 2. Regardless of the species of animals, $P$. pneumotropica, $M$. pulmonis, Sendai virus and Syphacia spp. were usually positive in more than 40 per cent of animals from colonies contaminated with these pathogens. On the contrary, animals positive for other pathogens, especially C. kutscheri, E. coli $\mathrm{O} 115 \mathrm{a}, \mathrm{c}: \mathrm{k}$ (B), Tyzzer's organism and MHV, were found at low frequencies; only 20 per cent or less of animals examined were demonstrated to be infected with these pathogens in more than a half of positive colonies.

In some animal colonies which had been known to be free of all the pathogens examined, except for $P$. aeruginosa, 
Table 3. Contaminants in mouse and rat colonies previously free from all pathogens except for $P$. aeruginosa

\begin{tabular}{lcc}
\hline \multicolumn{1}{c}{ Contaminant } & \multicolumn{2}{c}{ No. of colonies } \\
\cline { 2 - 3 } & Mouse & Rat \\
\hline $\begin{array}{l}\text { P. pneumotropica } \\
\text { Tyzzer's organism }\end{array}$ & 4 & 10 \\
Sendai virus & 3 & 1 \\
MHV & 2 & \\
Syphacia spp. & 4 & 6 \\
$\begin{array}{l}\text { P. pneumotropica and M. pulmonis } \\
\text { p. pneumotropica and Syphacia } \\
\text { Sendai virus and MHV (probably SDA) }\end{array}$ & 2 & 1 \\
\hline \multicolumn{1}{c}{ Total } & 15 & 20 \\
\hline
\end{tabular}

accidental contaminations with one or two pathogens were found by repeated examinations during various observation periods ranging 3 months to 9 years. Contaminants in these cases are listed in Table 3. $P$. pneumotropica and Syphacia spp. were commonly found as the contaminants in both mouse and rat colonies, occurring in 10 of 15 mouse colonies and in 17 of 20 rat colonies. However, some colonies were contaminated with Sendai virus, MHV, Tyzzer's organism, M. pulmonis and probably SDA virus.

Fujiwara et al [3] examined pathogen status of breeder and user colonies of mice and rats in this country by serological checking during a period from 1973 to 1978 and indicated high incidences of Sendai virus, $M$. pulmonis and MHV infections in user mouse colonies and Sendai virus, B. bronchiseptica, M. pulmonis, MHV and Tyzzer's organism infections in user and/or breeder rat colonies. Iwai et al [4] also performed serological and etiological monitoring of murine infections in user colonies from 1976 to 1978 , revealing high incidences of Sendai virus and Syphacia spp. infections in both mice and rats, and of $M$. pulmonis and probably SDA virus infections in rats. Although these pathogens were commonly found in conventional colonies examined in our study, it was worthy to note that nearly 90 per cent of conventional colonies were contaminated with both or either $P$. pneumotropica and Syphacia spp. and these two pathogens, especially $P$. pneu. motropica, were shown to be present in a majority of animals from positive colonies.

High incidence of Syphacia infection in breeder mouse and rat colonies was already reported by some researchers $[5,16]$, but actual status of $P$. pneumotropica infection in these colonies has been rarely investigated by previous workers. Iwai et al [4] found the organism in less than 10 per cent of user mouse and rat colonies, being significantly different from our cases. Such a discrepancy might be caused by different sources of animals, user or breeder colony, because $P$. pneumotropica was rarely isolated from SPF animals which were used by many researchers in this country.

On the other hand, SPF colonies which were grouped according to designation by breeders were usually free from all the pathogens examined including $P$. pneumotropica and Syphacia spp., except for $P$. aeruginosa, contamination of which seemed to be unavoidable even in barriered facilities.

Thus $P$. pneumotropica and Syphacia spp. were considered to be useful indica- 
tors to know pathogen status of mouse and rat breeding colonies. This consideration was also supported by the fact that accidental contaminations in animal colonies previously regarded as SPF was usually caused by these two pathogens.

\section{Acknowledgements}

The authors are indebted to Prof. K. Fujiwara, University of Tokyo, for supplying antigens of Tyzzer's organism and mouse hepatitis virus.

\section{References}

[1] Adachi, J., and Takagaki, Y. (1965). Bull. Exp. Anim., 14, 87-92 (Text in Japanese with English Summary).

[2] Bhatt, P. N., Percy, D. N., and Jonas, A. M. (1972). J. Inf. Dis., 126, 123-130.

[3] Fujiwara, K., Tanishima, Y., and Tanaka, M. (1979). Exp. Anim., 28, 297-306 (Text in Japanese with English summary).

[4] Iwai, H., Itoh, T., Kagiyama, N., and Nomura, T. (1980). In Animal Quality and Models in Biomedical Research, pp. 219-222, 7 th ICLAS Symposium, Utrechit 1979, Spiegel, A., Erichsen, S., and Solleveld, H. A. (eds.), Gustav Fischer Verlag, Stuttgart, New York.

[5] Kamiya, M., Oku, Y., Itoh, T., Kagiyama, N., and Iwai, H. (1979). Exp. Anim., 28, 409-413.

[6] Kojima, A., Fujinami, F., Doi, K., Yasoshima, A., and Okaniwa, A. (1980). Exp. Anim., 29, 409-418.
[7] Maejima, K., Urano, T., Itoh, K., and Fujiwara, K. (1972). Exp. Anim., 21, 13-18 (Text in Japanese with English summary).

[8] Mizuo, A., Shibuya, M., Nakagawa, M., Sami, S., Kiguchi, I., and Kurosawa, S. (1974). Exp. Anim., 23, 201 (Text in Japanese).

[9] Nakagawa, M., Muto, T., Nakano, T., Yoda, H., Ando, K., Isobe, Y., and Imaizumi, K. (1969). Exp. Anim., 18, 105-116.

[10] Nakagawa, M., Sakazaki, R., Muto, T., Saito, M., Hagiwara, T., and Imaizumi, K. (1969). Japan. J. Med. Sci. Biol., 22, 375-382.

[11] Saito, M., Kohjima, K., Sano, J., Nakayama, K., and, Nakagawa, M. (1981). Exp. Anim., 30, 313-316.

[12] Saito, M., Nakayama, K., and Nakagawa, M. (1976). Exp. Anim., 25, 265-272.

[13] Suzuki, E., Kinoshita, K., Muto, T., Nakagawa, M., and Imaizumi, K. (1982). Japan. J. Med. Sci. Biol., 35, 81-85.

[14] Suzuki, E., Matsubara, J., Saito, M., Muto, T., Nakagawa, M., and Imaizumi, K. (1982). Japan. J. Med. Sci. Biol., 35, 249-254.

[15] Tanaka, T., and Arai, T. (1958). Bull. Exp. Anim., 7, 138-144 (Text in Japanese with English summary).

[16] Tanaka., H., Ohshima, S., and Fujinami, F. (1974). Exp. Anim., 23, 15-30 (Text in Japanese with English summary).

[17] Utsumi, K., Matsui, Y., Ishikawa, T., Fukagawa, S., Tatsumi, H., Fujimoto, K., and Fujiwara, K. (1969). Exp. Anim., 18, 59-67 (Text in Japanese with English sammary).

[18] Utsumi, K., Maeda, T., Tatsumi, H., and Fujiwara, K. (1978). Exp. Anim., 27, 283-287 (Text in Japanese with English summary).

[19] Weisbroth, S. H., and Scher, S. (1968). Lab. Anim. Care, 18, 451-458.

\title{
マウスおよびラット生産コロニーの10年間にわたる病原体污染調查
}

\author{
中川雅郎·斉藤学・鈴木映子・中山一栄 \\ 松原純子・武藤健
}

国立予防衛生研究所獣疫部

1972１981年にかけて217のマウス,ラット生産コロニ 一を対象に11種の病原体 (P. aeruginosa, Salmonella spp., E. coli O115a, c: K(B), P. pneumotropica, $B$. bronchiseptica, C. kutscheri, Tyzzer 病菌, M. pulmonis, HVJ, MHV, Syphacia spp.) について污染調 査を行った。その結果, コンベンショナル動物ではマウ ス 89 コロニーとラット 64 コロニーの $90 \%$ 近くが $P$. pneumotropica と Syphacia spp. の両方または一方に 污染していた。HVJ, M. pulmonis, P. aeruginosa, $\mathrm{MHV}$ は51.7〜23.6\%のコロニーより検出され，さら に Tyzzer 病菌, B. bronchiseptica 拉よび SDA ウイル スと思われるものがラットコロニーの10\%以上で陽性を 示した。Salmonella spp., E. coli O115a, c : K(B), C. hutscheri のコロニー別検出率は数\%であった。 SPF 
動物では, マウス33とラット31コロニーの約1/3からP. aeruginosaが検出され, さらにラット3コロニーに $P$. pneumotropica の污染を認めた。

P. pneumotropica, M. pulmonis, HVJ, Syphacia spp. 污染 コロニーにおけるこれら病原体の個体別陽性 率は多くの場合 $40 \%$ 以上であった。一方, SPF コロニ 一の污染事故では P. pneumotropica と Syphacia spp. によるものが多かった。 